\title{
MENINGKATKAN KEMAMPUAN ESTIMASI ROUNDING TERHADAP PENJUMLAHAN MELALUI PEMBELAJARAN BERBANTUAN KARTU DAN GARIS BILANGAN PADA SISWA KELAS VB SDN 2 TAMAN SARI LOBAR
}

\author{
Oleh: Yuni Maryati
}

\begin{abstract}
Abstrak
The study was conducted to examine the improving ability of the estimation rounding of the students through assisted card learning and number line to describe the application of assisted learning and the number lines that improve the students rounding estimation's ability of VB class of 2 Taman Sari State Elementary School, West Lombok.This study used classroom action research. In this case, the researcher had a role as a conduit of action, a key instrument, a reporter of the research results, and an interviewer on the research subjects. The data of this study are in the form of the review of the student test answers and the interviews. The data was collected by researcher by using the student activity observation sheets, field notes, teacher observation sheets, guidelines for scoring test questions, and interviewing guides. The Result of the study shows thatthe application ofassisted card learningandthe number line which canimprove the ability of rounding estimationconsistsof5stages namely:(1) observingthe card and number line, (2) writing down the reasons of estimation in the card,(3) displaying card whichcontainsthe estimation resultan,(4) comparing the estimationrounding,(5) presenting thereasonswiththe card. The criteria of success which was specified by the researcher had been achieved in the second cycle. More detail the percentage of the students who did not make the mistake of the concepts, the calculations, and the procedures was as follows: (1) the percentage of the students who did not make the mistake of the concept was 76\%, (2) the percentage of the students who did not make the mistake of the procedures was $70 \%$, and (3) the percentage of the students who did not make the mistake of the calculation was 94\% and (4) the percentage of the students who had reached the KKM was $87 \%$.
\end{abstract}

Key Words: Ability, Rounding Estimation, Addition, Card, Line Numbers

\section{A. PENDAHULUAN}

Estimasi berhitung penting dalam keterampilan berpikir numerik (Kennedy, 2008: 173).Sejalan dengan hasil penelitian Jie, (1996);Tsao dan Pan, (2012)yang menyatakan bahwa sekitar $80 \%$ guru meyakini bahwa estimasi berhitung sangat penting dalam kehidupan sehari-hari, dan berfikir bahwa estimasi berhitung harus dimuat dalam kurikulum matematika. Pentingnya estimasi berhitung menjadikan estimasi sebagai sesuatu yang wajar dan perlu diajarkan pada siswa SD sebagai 
dasar untuk menumbuhkan dan mengembangkan keterampilan berhitung untuk memecahkan masalah dalam kehidupan sehari-hari. Ironisnya, estimasi tidak pernah diajarkan secara eksplisit dalam pembelajaran matematika di sekolah dasar karena tidak tercantum dalam standar kompetensi dalam pembelajaran matematika SD.

Berdasarkan hasil tes awal terhadap kemampuan estimasirounding siswa kelas VB SDN 2 Taman Sari Lombok Barat, diperoleh sebanyak 17 siswa mencapai nilai diatas 60 sehingga persentase ketuntasan minimal yang diperoleh hanya 51\% artinya belum mencapai KKM (Kriteria Ketuntasan Minimum) yang telah ditetapkan yaitu 80\%, selanjutnya dari analisiskesalahan siswa, dari hasil tes diperoleh 33 siswa mengalami kesulitan dalam memberikan alasan estimasi. Adapun jenis kesalahan yang lakukan oleh siswa akan dijabarkan sebagai berikut:(1) siswa melakukan kesalahan konsep dalam memaknai bahasa estimasi pada soal benar salah, dan salah menggunakan tekhnik pembulatan untuk soal dengan bahasa estimasi cukup atau tidak cukup, (2) siswa menggunakan perhitungan bersusun atau perhitungan yang menghasilkan jawaban eksak (pasti). Walaupun sudah ditegaskan supaya mereka tidak menggunakan algoritma untuk mengestimasi, tetapi yang dilakukan adalah menggunakan algoritma kemudian baru mengatakan bahwa itu hasil estimasinya.

Selanjutnya dari hasil pengamatan observasi kelas dan dialog dengan guru kelas VB SDN 2 Taman Sari, diperoleh informasi bahwa pembelajaran matematika di kelas VB umumnya menggunakan metode ceramah dengan alur pembelajaran sebagai berikut: guru mengajar lalu siswa mendengar, guru memberi contoh soal lalu siswa meniru dan mencatat, guru memberi soal latihan lalu siswa mengerjakan soal tersebut dengan mengikuti contoh soal yang diberikan guru. Pembelajaran seperti ini tidak membantu siswa terlibat aktif dalam pembelajaran, sehingga tidak memberikan makna bagi siswa yang menyebabkan siswa mudah lupa terhadap apa yang dipelajarinya dan hampir dalam pembelajaran matematika tidak pernah menggunakan media.

Berakar dari hasil observasi awal, penulis berpendapat bahwa yang harus diperbaiki adalah mencari dan memilih model pembelajaran matematika yang 
menarik, memotivasi, mudah dipahami siswa, menantang siswa untuk terlibat dan pada akhirnya menjadikan siswa terampil sehingga dapat meningkatkan kemampuan estimasi. Salah satu model pembelajaran matematika yang menarik, memotivasi, mudah dipahami siswa, menantang siswa dan menjadikan siswa lebih terampil adalah dengan menggunakan bahan manipulatif. Penggunaan bahan manipulatif memberikan beberapa keuntungan yaitu (1) dapat meningkatkan minat dan motivasi siswa, (2) membantu siswa memvisualisasikan secara konkret, (3) membantu siswa memahami dan memperkuat konsep, (4) dapat digunakan untuk pendahuluan konsep, dan (5) mendorongbahasa lisan. (Swan\&Marshal (2010:16 ). Sejalan dengan hasil penelitian Boggan, M., Harper,S., \& Whitmire, A. (2010) menyatakan keuntungan penggunaan bahan manipulatif yaitu dapat membantu siswa dalam menghubungkan ide dan mengintegrasikan pengetahuan mereka sehingga mereka mendapatkan pemahaman yang mendalam tentang konsep matematika sebagai langkah pertama menuju pemahaman proses matematika dan prosedur. Dalam hal sarana-prasarana untuk peningkatan kemampuan estimasi,kartu dan garis bilangan memenuhi syarat untuk dipilih sebagai media bahan manipulatif sebab sesuai dengan kondisi siswa, mudah didapatkan, murah, dan cocok. Pemilihan kartu dan garis bilangan sebagai media dalam penelitian ini sesuai dengan pendapat Usman dan Asnawir(2002: 15-16), diantaranya: (1) Selaras dan menunjang tujuan pembelajaran yang telah ditetapkan, (2) Sesuai dengan kondisi siswa, yaitu umur, intelegensi, latar belakang pendidikan, budaya, dan lingkungan siswa, (3) Tersedia di sekolah atau dapat dibuat oleh guru, (4) Memerlukan biaya yang relatif tidak banyak. Kartu bilangan digunakan sebagai model untuk menggambarkan bilangan-bilangan yang digunakan dalam melakukan estimasi dan garis bilangan digunakan untuk menggambarkan nilai tempat agar mempermudah siswa memaknai bilangan estimasi yaitu lebih besar, lebih kecil atau bilangan berada di antara bilangan acuan.

Dari hasil observasi awal dan kelebihan penggunaan media kartu dan garis bilangan yang telah dijabarkan, peneliti mengambil inisiatif untuk meningkatkan kemampuan estimasi dengan pembelajaran berbantuan kartu dan garis bilangan 
untuk membuat siswa aktif, membuat pembelajaran lebih bermakna dan menyenangkan sehingga peneliti mencoba melakukan penelitian yang berjudul “Meningkatkan Kemampuan Estimasi Rounding Terhadap Penjumlahan Melalui Pembelajaran Berbantuan Kartu dan Garis Bilangan Pada Kelas VB SDN 2 Taman Sari Lombok Barat"

Adapun kriteria kemampuanestimasi roundingsiswa dikatakan meningkat dalam penelitian ini jika siswa dapat memberikan alasan yang logis dalam melakukan estimasi dengan waktu yang ditentukan (Rubenstein; Grouws, 1992: 371). Waktu yang ditentukan dalam melakukan estimasi adalah maksimal 10 menit untuk setiap butir soal. Selanjutnya, seorang siswa dikatakan logis dalam melakukan estimasi, jika tidak melakukan kesalahan konsep, prosedur dan kalkulasi. Lebih khusus dalam penelitian ini, kemampuan estimasi meningkat jika jumlah siswa tidak melakukan kesalahan konsep, prosedur dan kalkulasi pada saat mengerjakan tes minimal adalah 60\%. Selain tidak melakukan kesalahan konsep, prosedur dan kalkulasi, kemampuan estimasi siswa dikatakan meningkat jika minimal 80\% jumlah siswa mencapai skor minimal 60 dalam menyelesaikan soalsoal estimasi.

Penelitian ini menggunakan penelitian tindakan kelas. Untuk setiap siklusnya peneliti hadir sebanyak tiga kali pertemuan. Kehadiran peneliti dapat berperan secara fisik dan non fisik. Kehadiran peneliti secara fisik yaitu sebagai pemberi tindakan yang artinya peneliti berperan sebagai pengajar yang membuat rancangan pembelajaran sekaligus melaksanakan pembelajaran selama berlangsungnya kegiatan penelitian. Selain sebagai pemberi tindakan peneliti juga berperan sebagai instrumen kunci yaitu bertindak sebagai pengumpul data. Selain sebagai pemberi tindakan dan instrumen kunci, peneliti juga bertindak sebagai pelapor hasil penelitian dan pewawancara terhadap subjek penelitian. Selanjutnya kehadiran peneliti secara non fisik adalah peneliti berperan sebagai perancang, penyumbang ide, dan pemeran utama dalam pelaksanaan kegiatan pembelajaran.

Penelitian meningkatkan kemampuan estimasi roundingterhadap penjumlahan dilakukan di SDN 2 Taman Sari Lombok Barat yang beralamat di Jalan Raya Tanjung Kecamatan Gunung sari Kabupaten Lombok Barat. Penelitian ini 
dilaksanakan pada semester genap tahun pelajaran 2012/2013 di kelas VB, sehingga yang menjadi subjek dalam penelitian ini adalah siswa kelas VB yang berjumlah 33 orang siswa.

Tahap-tahap penelitian ini terdiri atas (1) penetapan fokus penelitian yaitu peneliti melakukan observasi awal, memberikan tes awal pada siswa, dan memvalidasi perangkat pembelajaran dan instrumen penelitian kepada validator, (2) perencanaan tindakan yaitu menyiapkan dan menyusun instrumen penelitian, (3) pelaksanaan tindakan yaitu mengimplementasikan Rencana Pelaksanaan Pembelajaran (RPP) dengan berbantuan kartu dan garis bilangan dan mengadakan tes akhir, (4) observasi dan interpretasi yaitu merekam kegiatan pembelajaran siswa selama proses pemberian tindakan dan melakukan wawancara, (5) analisis dan refleksi yaitu mengkaji jawaban siswa untuk setiap butir tes soal kemudian mengelompokkannya berdasarkan kesalahan konsep, prosedur, dan kalkulasi, menghitung skor rata-rata tes akhir siswa, mendeskripsikan data dari hasil observasi, catatan lapangan dan wawancara, serta melakukan refleksi (memikirkan ulang apa yang sudah dilakukan, apa yang belum dilakukan, dan apa yang perlu disempurnakan).

Bentuk instrumen penelitian yang akan digunakan dalam penelitian meningkatkan kemampuan estimasi rounding terhadap penjumlahan adalah sebagai berikut: (1) tes yang berupa soal uraian terkait estimasi penjumlahan bilangan asli, (2) lembar observasi, (3) catatan lapangan (4) wawancara, (5) lembar validasi.

Setelah data yang terdiri dari lembar observasi kegiatan guru, lembar observasi kegiatan siswa, hasil tes awal dan tes akhir, serta hasil wawancara sudah terkumpul, proses selanjutnya adalah melakukan analisis. Tahapan analisis data yang digunakan dalam penelitian ini terdiri dari 3 tahap yaitu (1) mereduksi data yaitu menelusuri dan mengelompokkan jenis kesalahan yang dilakukan siswa berdasarkan kesalahan konsep, prosedur, dan kalkulasi, (2) menyajikan data yaitu membuat grafik untuk mengetahui sebaran data tentang hasil tes siswa, (3) menarik kesimpulan dan verifikasi data yaitu mengecek dan memeriksa serta menelusuri kesalahan konsep, prosedur, dan kalkulasi yang terjadi pada hasil tes 
siswa pada setiap butir tes. Selanjutnya peneliti memanggil siswa yang masih mengalami kesalahan untuk ditanya atau diverifikasi tentang letak kesalahannya, selain itu melakukan wawancara untuk mengetahui tanggapan siswa terhadap pembelajaran estimasi rounding berbantuan kartu dan garis bilangan. Hasil penarikan kesimpulan dan verifikasi ini menentukan perlu tidaknya dilakukan siklus berikutnya.

\section{B. PEMBAHASAN}

Suasana belajar matematika terhadap materi estimasi rounding penjumlahan dengan menerapkan kartu dan garis bilangan berlangsung sangat menyenangkan. Berdasarkan hasil pengamatan, siswa terlibat aktif dalam melakukan estimasi rounding dengan mendiskusikan LKS bersama dengan kelompoknya. Secara lebih rinci,suasana belajar matematika estimasi rounding terhadap penjumlahan dengan pembelajaran berbantuan kartu dan garis bilangan tersaji pada tabel berikut.

\section{Tabel 1.1 Indikator Suasana Belajar}

\begin{tabular}{|c|c|c|c|}
\hline No & Suasana Belajar & Indikator & Keterangan \\
\hline 1. & Menyenangkan & $\begin{array}{l}\text { Siswa terlibat sendiri dalam } \\
\text { menuliskan hasil estimasi pada kartu } \\
\text { kosong dan menempelkan hasil } \\
\text { estimasi yang berupa kartu bilangan } \\
\text { yang terbuat dari kain fanel }\end{array}$ & $\begin{array}{l}\text { Siswa aktif dalam } \\
\text { mengerjakan tugas }\end{array}$ \\
\hline 2. & $\begin{array}{l}\text { Siswa terlibat } \\
\text { aktif }\end{array}$ & $\begin{array}{l}\text { Siswa Membandingkan hasil estimasi } \\
\text { yang ditampilkan pada papan fanel dan } \\
\text { mempresentasikan jawaban dengan } \\
\text { mengkomunikasikan alasan estimasi } \\
\text { di hadapan teman-teman mereka dan } \\
\text { siswa dapat menyampaikan pendapat } \\
\text { pada saat guru memberikan respon } \\
\text { berupa pertanyaan secara lisan. }\end{array}$ & Siswa saling tanyajawab \\
\hline 3. & $\begin{array}{l}\text { Siswa } \\
\text { menemukan pola }\end{array}$ & $\begin{array}{l}\text { Siswa membulatkan setiap bilangan, } \\
\text { kemudian melakukan komputasi dan } \\
\text { selanjutnya menyimpulkan dengan } \\
\text { menyesuaikan tekhnik yang digunakan } \\
\text { dalam estimasi pembulatan dengan } \\
\text { pilihan jawaban }\end{array}$ & $\begin{array}{l}\text { Siswa dapat memberikan } \\
\text { alasan terhadap estimasi yang } \\
\text { dilakukan }\end{array}$ \\
\hline 4. & $\begin{array}{l}\text { Memudahhkan } \\
\text { siswa dalam } \\
\text { memberikan } \\
\text { alasan }\end{array}$ & $\begin{array}{l}\text { Siswa dapat mengkomunikasikan } \\
\text { alasan estimasi yang dilakukan }\end{array}$ & $\begin{array}{l}\text { Siswa dapat } \\
\text { mengkomunikasikan alasan } \\
\text { kepada teman-temannya baik } \\
\text { di dalam anggota kelompok } \\
\text { maupun di hadapan semua } \\
\text { kelompok }\end{array}$ \\
\hline
\end{tabular}


5. Kegiatan belajar dilakukan secara bertahap.
Siswa melakukan kegiatan belajar estimasi rounding melalui tahapan eksplorasi, elaborasi, dan konfirmasi.
6. Melatih siswa untuk percaya diri dan menghargai pendapat teman
Siswa percaya diri dalam mempresentasikan alasan estimasi yang dilakukan di depan semua kelompok dan memberikan tanggapan terhadap hasil pekerjaan setiap kelompok a. Pada tahap eksplorasi siswa terlibat langsung untuk mengerjakan soal LKS, membagi tugas antar anggota kelompok dalam mengerjakan LKS dan saling membantu dengan teman satu kelompok.

b. Pada tahap elaborasi siswa menampilkan hasil estimasi, membandingkan dan mempresentasikan alasan dihadapan temantemannya

c. Pada tahap konfirmasi: mempertegas jawaban yang benar sehingga mengarahkan siswa untuk membuat kesimpulan yaitu langkah-langkah pemberikan alasan dalam melakukan estimasi

Siswa tidak canggung atau malu untuk mengkomunikasikan alasan estimasi

Selain dari hasil pengamatan, data dari hasil wawancara juga diperoleh fakta bahwa siswa merasa senang belajar estimasi rounding karena beberapa alasan berikut: (a) siswa senang belajar estimasi karena sebelumnya tidak pernah diajarkan estimasi, (b) siswa senang menulis bilangan pada kartu, (c) siswa senang menempelkan atau menampilkan kartu pada garis bilangan (papan fanel) dan (d) siswa senang mempresentasikan alasan dengan menggunakan kartu.

Pembelajaran berbantuan kartu dan garis bilangan pada materi estimasi roundingdisusun untuk meningkatkan kemampuan estimasi siswa dalam melakukan estimasi penjumlahan. Hal ini dilakukan untuk menjadikan siswa sadar akan peranan matematika kuhusunya estimasi dalam kehidupan sehari-hari dengan pemahaman yang didukung oleh alasan yang benar sehingga mempunyai makna dan rasional. Sejalan dengan pendapat Suherman (2001), pembelajaran 
matematika diharapkan memunculkan efek iringan berupa kesadaran siswa tentang peranan matematika dalam kehidupan sehari-hari, yang pada akhirnya menjadikan siswa mampu berfikir logis, kritis, sistematis, kreatif dan inovatif dalam mencari solusi pemecahan suatu masalah dalam kehidupan sehari-hari.

Agar siswa dapat mencapai kemampuan estimasi yang dimaksud, peneliti menerapkan langkah-langkahpembelajaran menggunakan kartu dan garis bilangan yang dapat meningkatkan kemampuan estimasi rounding khususnya pada siswa kelas VBSDN 2 Taman Sari Lombok Barat. Secara umum langkah-langkah yang dilakukan adalah sebagai berikut: (a) Siswa mengamati kartu dan garis bilangan yang menjelaskan tentang konsep pembulatan dalam estimasi rounding dan langkah-langkah dalam memberikan alasan estimasi dengan kartu, (b) Siswa menuliskan bilangan hasil pembulatan dan hasil penjumlahan pembulatan pada kartu kosong, (c) Siswa menampilkan kartu kosong yang telah diisi dengan bilangan hasil pembulatan dan hasil penjumlahan pembulatan, (d) Siswa membandingkan hasil estimasi semua kelompok yang telah ditampilkan, (e) Siswa menjelaskan alasan jawabannya melalui presentasi kartu.

Penerapan pembelajaran berbantuan kartu dan garis bilangan ini telah dapat meningkatkan kemampuan estimasi rounding siswa, dimana jika diberikan operasi penjumlahan, siswa dapat memberikan alasan dengan tepat yaitu siswa melakukan pembulatan, dilanjutkan dengan komputasi dari hasil pembulatan dan selanjutnya siswa diarahkan dalam menyesuaikan hasil estimasi dengan pilihan jawaban yang telah disediakan. Secara lebih rinci, berikut penjabaran data hasil tes untuk melihat peningkatan kemampuan estimasi rounding siswa kelas VB SDN 2 Taman Sari Lombok Barat.

Berdasarkan hasil tes akhir siklus I, diperoleh data yaitu;

1) Sebanyak 16 siswa melakukan kesalahan konsep. Dengan kata lain 17 siswa dari 33 siswayang mengikuti tes dinyatakan sudah tidak melakukan kesalahan konsep. Jadi dari informasi ini dapat disimpulkan bahwa persentase siswa yang tidak melakukan kesalahan konsep adalah 51\%. Secara rinci jenis kesalahan konsep yang telah dilakukan oleh siswa adalah (1) Tekhnik pembulatan yang digunakan salah yaitu siswa menggunakan tekhnik 
pembulatan bawah untuk mencari hasil estimasi dari soal yang memperkirakan cukup atau tidak cukupnya uang yang dimiliki untuk membeli makanan atau minuman, (2) siswa menggunakan perhitungan bersusun atau perhitungan yang menghasilkan jawaban eksak (pasti), dan (3) siswa salah dalam menyesuaikan hasil pembulatan yang dilakukan dengan pilihan jawaban yang tersedia.

2) Sebanyak 17 siswa melakukan kesalahan prosedur. Dengan kata lain 16 orang dari 33 siswa yang mengikuti tes dinyatakan sudah tidak mengalami kesalahan prosedur. Jadi dapat disimpulkan bahwa persentase siswa yang tidak melakukan kesalahan prosedur adalah 48\%. Secara rinci jenis kesalahan prosedur yang telah dilakukan siswa adalah: (1) Siswa hanya menuliskan tekhnik perhitungan atau pembulatan yang digunakan, akan tetapi tidak menjabarkan operasi pembulatan yang digunakan dan (2) siswa hanya melakukan pembulatan sebagian artinya siswa hanya membulatkan satu atau dua bilangan (ada bilangan yang tidak dibulatkan) dan tidak menuliskan hasil penjumlahan dari bilangan-bilangan yang dibulatkan.

3) Sebanyak 6 siswa melakukan kesalahan kalkulasi. Dengan kata lain 27 orang dari 33 siswa yang mengikuti tes dinyatakan sudah tidak mengalami kesalahan kalkulasi. Jadi dapat disimpulkan bahwa persentase siswa yang tidak melakukan kesalahan kalkulasi adalah 82\%. Secara rinci jenis kesalahan kalkulasi yang telah dilakukan siswa adalah siswa kurang teliti dalam melakukan operasi penjumlahan akibatnya mereka salah dalam memilih pilihan jawaban estimasi.

4) Sebanyak 23 siswa atau 70\% siswa sudah mencapai KKM (Kriteria Ketuntasan Minimum) yang telah ditetapkan yaitu 60.

Pada hasil tes akhir siklus II, diperoleh data yaitu:

1) Sebanyak 8 siswa melakukan kesalahan konsep. Dengan kata lain 25 siswa dari 33 siswa yang mengikuti tes dinyatakan sudah tidak melakukan kesalahan konsep. Jadi dari informasi ini dapat disimpulkan bahwa persentase siswa yang tidak melakukan kesalahan konsep adalah 76\%. 
2) Sebanyak 10 siswa melakukan kesalahan prosedur. Dengan kata lain 23 orang dari 33 siswa yang mengikuti tes dinyatakan sudah tidak mengalami kesalahan prosedur. Persentase siswa yang tidak melakukan kesalahan prosedur adalah $70 \%$.

3) Sebanyak 2 siswa melakukan kesalahan kalkulasi. Dengan kata lain 31 orang dari 33 siswa yang mengikuti tes dinyatakan sudah tidak mengalami kesalahan kalkulasi. Jadi dapat disimpulkan bahwa persentase siswa yang tidak melakukan kesalahan kalkulasi adalah 94\%.

4) Sebanyak 29 siswa atau 87\% siswa sudah mencapai KKM (Kriteria Ketuntasan Minimum).

Secara keseluruhan data hasil penelitian siklus I dan siklus II dapat dilihat pada tabel berikut.

Tabel 1.2 Persentase Kriteria Keberhasilan

\begin{tabular}{lll}
\hline Kriteria Ketercapaian & Siklus I & Siklus II \\
\hline Persentase siswa yang mencapai KKM & $70 \%$ & $87 \%$ \\
Tinjauan Jenis Kesalahan & & \\
Persentase siswa yang tidak mengalami Kesalahan Konsep & $51 \%$ & $76 \%$ \\
Persentase siswa yang tidak mengalami Kesalahan Prosedur & $48 \%$ & $70 \%$ \\
Persentase siswa yang tidak mengalami Kesalahan Kalkulasi & $82 \%$ & $94 \%$ \\
\hline
\end{tabular}

Berdasarkan tabel di atas terlihat bahwa kemampuan estimasi siswa mengalami peningkatan dari siklus I ke siklus II yaitu meningkatnya persentase siswa yang mencapai KKM. Pada siklus I persentase siswa yang mencapai KKM adalah sebesar 70\% kemudian persentase siswa yang mencapai KKM pada siklus II meningkat menjadi 87\%. Selanjutnya persentase siswa yang tidak mengalami kesalahan konsep naik dari siklus I sebesar 51\% menjadi 76\% pada siklus II. Untuk persentase siswa yang tidak mengalami kesalahan prosedur naik dari $48 \%$ menjadi 70\%. Dan persentase siswa yang tidak mengalami kesalahan kalkulasi dari siklus I sebesar 82\% dan pada siklus II menjadi 94\%.

Pelaksanaan penelitian yaitu dengan menerapkan media kartu dan garis bilangan untuk meningkatkan kemampuan estimasi rounding siswa terhadap penjumlahan tidak terlepas dari berbagai kendala. Kendala yang dihadapi peneliti 
selama melaksanakan penelitian ini harus segera dicari solusinya agar tidak menjadi hambatan untuk mencapai tujuan penelitian. Kendala-kendala dan pemecahannya tersaji pada tabel berikut.

Tabel 1.3 Kendala dan SolusiPenelitian

\begin{tabular}{|c|c|}
\hline Kendala Penelitian & Solusinya \\
\hline $\begin{array}{l}\text { a. Ada beberapa siswa yang tidak bekerja } \\
\text { secara maksimal dalam diskusi } \\
\text { kelompok alasannya karena LKS yang } \\
\text { diberikan hanya satu LKS untuk satu } \\
\text { kelompok, selain itu siswa masih sangat } \\
\text { kebingungan Karen estimasi } \\
\text { merupakan materi yang baru mereka } \\
\text { pelajari }\end{array}$ & $\begin{array}{l}\text { Merubah susunan anggota kelompok pada siklus } \\
\text { II tetapi tetap memperhatikan kategori } \\
\text { kemampuan dan jenis kelamin siswa. Selain itu } \\
\text { menyiapkan LKS kelompok lebih banyak sehingga } \\
\text { setiap kelompok mendapatkan dua LKS }\end{array}$ \\
\hline $\begin{array}{l}\text { b. Beberapa siswa yang duduk di bangku } \\
\text { belakang merasa kesulitan pada waktu } \\
\text { membandingkan hasil estimasi yang } \\
\text { ditempelkan pada papan fanel, hal ini } \\
\text { disebabkan karena ukuran kartu yang } \\
\text { terlalu kecil }\end{array}$ & $\begin{array}{l}\text { Menyiapkan kartu dengan ukuran yang lebih } \\
\text { besar, dan meminta siswa untuk menuliskan } \\
\text { bilangan dengan ukuran besar dan ditebalkan dan } \\
\text { dengan masukan dari observer, peneliti } \\
\text { menyiapkan kartu dengan enam kartu yang } \\
\text { berbeda untuk setiap kelompok agar lebih } \\
\text { menarik }\end{array}$ \\
\hline $\begin{array}{l}\text { c. Ada siswa yang kurang jelas dengan } \\
\text { petunjuk kerja pada LKS yang } \\
\text { disebabkan karena kurangnya jelasnya } \\
\text { arahan dan gambar dalam LKS }\end{array}$ & $\begin{array}{l}\text { Melakukan revisi yaitu dengan lebih memperjelas } \\
\text { contoh dengan melengkapi gambar dan petunjuk } \\
\text { kerja pada LKS siklus II. }\end{array}$ \\
\hline $\begin{array}{l}\text { d. Ada beberapa siswa yang kurang } \\
\text { memahami maksud soal }\end{array}$ & $\begin{array}{l}\text { Meminta siswa untuk membaca kembali soal yang } \\
\text { kurang dapat dipahami kemudian membantu } \\
\text { mengarahkan siswa dengan memberikan } \\
\text { pertanyaan yang dapat memancing respon siswa. }\end{array}$ \\
\hline $\begin{array}{l}\text { e. Ada siswa yang asyik bermain sendiri } \\
\text { dengan kartu dan garis bilanag ketika } \\
\text { presentasi berlangsung. }\end{array}$ & $\begin{array}{l}\text { Mengawasi aktivitas siswa selama kegiatan } \\
\text { diskusi berlangsung dan membuat aturan dengan } \\
\text { siswa bahwa ketika presentasi, siswa diminta } \\
\text { untuk meletakan kartu dan garis bilangan di atas } \\
\text { meja sehingga tidak ada siswa yang asyik bermain } \\
\text { sendiri. }\end{array}$ \\
\hline
\end{tabular}

\section{PENUTUP}

Berdasarkan rumusan masalah dan hasil penelitian, dapat disimpulkan beberapa hal sebagai berikut: (1) Penerapan pembelajaran menggunakan kartu dan garis bilangan yang dapat meningkatkan kemampuan estimasi pada siswa kelas VB SDN 2 Taman Sari Lombok Barat terdiri dari 5 tahap yaitu: (a) Siswa mengamati kartu dan garis bilangan yang menjelaskan tentang konsep pembulatan dalam estimasi rounding dan langkah-langkah dalam memberikan alasan estimasi dengan kartu, (b) Siswa menuliskan bilangan hasil pembulatan dan hasil penjumlahan pembulatan pada 
kartu kosong, (c) Siswa menampilkan kartu kosong yang telah diisi dengan bilangan hasil pembulatan dan hasil penjumlahan pembulatan, (d) Siswa membandingkan hasil estimasi semua kelompok yang telah ditampilkan, (e) Siswa menjelaskan alasan jawabannya melalui presentasi kartu. Selanjutnya, (2) Terjadi peningkatan kemampuan estimasi rounding siswa terhadap penjumlahan dengan diterapkannya pembelajaran berbantuan kartu dan garis bilangan. Secara lebih rinci, persentase peningkatan kemampuan estimasi rounding siswa kelas VB SDN 2 Taman Sari Lombok Barat adalah sebagai berikut: (a) Pada siklus I persentase siswa yang mencapai KKM adalah sebesar 70\% kemudian persentase siswa yang mencapai KKM pada siklus II meningkat menjadi 87\%., (b) Selanjutnya persentase siswa yang tidak mengalami kesalahan konsep meningkat dari siklus I sebesar 51\% menjadi 76\% pada siklus II, (c) Untuk persentase siswa yang tidak mengalami kesalahan prosedur meningkat dari siklus I sebesar 48\% menjadi 70\% pada siklus II, (d) Persentase siswa yang tidak mengalami kesalahan kalkulasi meningkat dari siklus I sebesar 82\% menjadi $94 \%$ pada siklus II.

Berdasarkan hasil penelitian yang dilakukan peneliti, disarankan kepada guru matematika SD agar menaksir (estimasi) diperkenalkan lebih banyak dalam setiap kesempatan yang ada. Untuk meningkatkan kemampuan menaksir (estimasi) salah satu alternatif yang dapat dilakukan mengarahkan siswa untuk melakukan estimasi dengan menggunakan media kartu dan garis bilangan pada operasi pengurangan, perkalian dan pembagian pada bilangan asli maupun bilangan desimal dengan menggunakan tekhnik estimasi yang lain seperti round 5 Up dan compatible number.

\section{DAFTAR PUSTAKA}

Boggan, M., Harper, S., \& Whitmire, A. Using manipulatives to teach elementary mathematics. Journal of Instructional Pedagogies, page 7.

Grouws D.A. 1992. Handbook for Research on Mathematics Teaching and Learning. New York: Macmillan Publishing Company.

Kennedy, L.M., Tipps, S., \& Johnson, A. 2008. Guiding Children's Learning of Mathematics. Belmont California: Thomson Wadsworth Publishing Company. 
Suherman, E. 2001. Strategi Pembelajaran Matematika Kontemporer. Bandung: Universitas Pendidikan Indonesia.

Swan, P. \& Marshal, L. 2010. Revisiting Mathematics Manipulative Materials. Jurnal Gale, (Online), 15 (2): 13-19. (http://infotrac.galegroup.com/itweb), diakses 9 Juli 2013.

Tsao, Y.L.\& Pan, T.R. 2012. The computational estimation and instructional perspectives of elementary school teachers. Journal of Instructional Pedagogies, page 7 . Table 2 .

Usman, M. B. dan Asnawir. 2002. Media Pembelajaran. Jakarta: Ciputat Pers. 